\title{
Characterization of SR 121463A, a Highly Potent and Selective, Orally Active Vasopressin $\mathrm{V}_{2}$ Receptor Antagonist
}

\author{
Claudine Serradeil-Le Gal,, Colette Lacour, ${ }^{\ddagger}$ Gérard Valette, ${ }^{\star}$ Georges Garcia, ${ }^{\ddagger}$ Loïc Foulon, ${ }^{\star}$ Gérard Galindo, ${ }^{\ddagger}$ Lise Bankir, ${ }^{\S}$ \\ Brigitte Pouzet, ${ }^{\S}$ Gilles Guillon, Claude Barberis," Danielle Chicot, \\ Danielle Raufaste, ${ }^{\star}$ Gabrielle Brossard, ${ }^{*}$ Dino Nisato, ${ }^{\ddagger}$ Jean Pierre Maffrand, ${ }^{,}$and Gérard Le Fur ${ }^{\star}$ \\ *Sanofi Recherche, Exploratory Research Department, 31036 Toulouse Cedex, France; ${ }^{\star}$ Sanofi Recherche, Cardiovascular Department, \\ 34184 Montpellier Cedex, France; ${ }^{\S}$ INSERM U 90, Hôpital Necker, 75743 Paris Cedex, France; and INSERM U 401, Rue de la \\ Cardonille, 34094 Montpellier Cedex, France
}

\begin{abstract}
SR 121463A, a potent and selective, orally active, nonpeptide vasopressin $V_{2}$ receptor antagonist, has been characterized in several in vitro and in vivo models. This compound displayed highly competitive and selective affinity for $\mathrm{V}_{2}$ receptors in rat, bovine and human kidney $\left(0.6 \leq K_{\mathrm{i}}[\mathrm{nM}]\right.$ $\leq 4.1)$. In this latter preparation, SR 121463 A potently antagonized arginine vasopressin (AVP)-stimulated adenylyl cyclase activity $\left(K_{\mathrm{i}}=0.26 \pm 0.04 \mathrm{nM}\right)$ without any intrinsic agonistic effect. In autoradiographic experiments performed in rat kidney sections, SR 121463A displaced [ $\left.{ }^{3} \mathrm{H}\right] \mathrm{AVP}$ labeling especially in the medullo-papillary region and confirmed that it is a suitable tool for mapping $\mathrm{V}_{2}$ receptors. In comparison, the nonpeptide $\mathrm{V}_{2}$ antagonist, OPC-31260, showed much lower affinity for animal and human renal $V_{2}$ receptors and lower efficacy to inhibit vasopressin-stimulated adenylyl cyclase ( $K_{\mathrm{i}}$ in the 10 nanomolar range). Moreover, OPC-31260 exhibited a poor $V_{2}$ selectivity profile and can be considered as a $\mathrm{V}_{2} / \mathrm{V}_{1 \mathrm{a}}$ ligand. In normally hydrated conscious rats, SR $121463 \mathrm{~A}$ induced powerful aquaresis after intravenous $(0.003-0.3 \mathrm{mg} / \mathrm{kg})$ or oral $(0.03-10 \mathrm{mg} / \mathrm{kg})$ administration. The effect was dose-dependent and lasted about 6 hours at the dose of $3 \mathrm{mg} / \mathrm{kg}$ p.o. OPC-31260 had a similar aquaretic profile but with markedly lower oral efficacy. The action of SR $121463 \mathrm{~A}$ was purely aquaretic with no changes in urine $\mathrm{Na}^{+}$and $\mathrm{K}^{+}$excretions unlike that of known diuretic agents such as furosemide or hydrochlorothiazide. In addition, no antidiuretic properties have been detected with SR 121463A in vasopressin-deficient Brattleboro rats. Thus, SR 121463A is the most potent and selective, orally active $V_{2}$ antagonist yet described and could be a powerful tool for exploring $V_{2}$ receptors and the therapeutical usefulness of $\mathrm{V}_{2}$ blocker aquaretic agents in water-retaining diseases. (J. Clin. Invest. 1996. 98:2729-2738.) Key words: SR $121463 \mathrm{~A} \cdot$ vasopressin • nonpeptide antagonist • $\mathrm{V}_{2}$ receptor $\cdot$ aquaretic
\end{abstract}

Address correspondence to C. Serradeil-Le Gal, Sanofi Recherche, 195 route d'Espagne, 31036 Toulouse Cedex, France. Phone: 33561 1623 84; FAX: 33561162586.

Received for publication 10 June 1996 and accepted in revised form 10 October 1996.

J. Clin. Invest.

(C) The American Society for Clinical Investigation, Inc. 0021-9738/96/12/2729/10 \$2.00

Volume 98, Number 12, December 1996, 2729-2738

\section{Introduction}

The importance of arginine vasopressin $(\mathrm{AVP})^{1}$ in the regulation of blood pressure and volume and in the control of fluid and electrolyte balance is well established. AVP plays a major role as an antidiuretic hormone regulating water and solute excretion by the kidney through specific interaction with the renal $\mathrm{V}_{2}$ receptors present all along the collecting duct from cortex to papilla in the mammalian nephron $(1,2)$.

So far, three AVP receptors subtypes, $V_{1 \mathrm{a}}, \mathrm{V}_{1 \mathrm{~b}}$, and $\mathrm{V}_{2}$ have been identified based upon their primary structure (3-10), their coupling mechanisms, their tissular distributions and their pharmacological properties (for review see 11, 12). The $\mathrm{V}_{2}$ receptor belongs to the seven transmembrane $\mathrm{G}$ proteincoupled receptor superfamily and is positively coupled to a Gs/ adenylyl cyclase system. This $\mathrm{V}_{2}$ receptor has been cloned in different species including rat, pig, bovine and human (7-10). Moreover, several constitutive AVP $\mathrm{V}_{2}$ receptor gene mutations have now been identified as the molecular basis for the lack of urine concentration in Nephrogenic Diabetes Insipidus $(13,14)$.

Receptor-specific AVP V $\mathrm{V}_{2}$ antagonists, so-called "aquaretic agents," able to block the action of AVP in the collecting duct cells and thus to promote specifically water excretion, could be of high therapeutical value for the treatment of several waterretaining disorders such as SIADH (Syndrome of Inappropriate Antidiuretic Hormone secretion), liver cirrhosis, certain stages of congestive heart failure and hypertension, nephrotic syndrome (15-18). In most of these diseases an abnormal increase of circulating AVP plasma level, activating renal $\mathrm{V}_{2}$ receptors, seems to be the key event in water retention and subsequent hypotonic hyponatremia (18-20). Thus, for these pathologies, there is great clinical interest in the development of potent $\mathrm{V}_{2}$ receptor antagonists to provide specific water diuretic/aquaretic compounds devoid of the well-known side effects of classical diuretic or saliuretic agents on the solute excretion (urine $\mathrm{Na}^{+}$and/or $\mathrm{K}^{+}$loss).

Although several potent peptide vasopressin $\mathrm{V}_{2}$ receptor antagonists have been synthesized, the evaluation of their therapeutic utility has been severely hampered by their lack of oral bioavailability, species differences and especially by their agonist antidiuretic effects when tested in man (21). Recent years have marked a turning point with the design of the first nonpeptide, orally effective AVP $\mathrm{V}_{1 \mathrm{a}}$ and $\mathrm{V}_{2}$ receptor antago-

1. Abbreviations used in this paper: AVP, arginine vasopressin; cAMP, cyclic adenosine monophosphate; DI, diabetes insipidus; OT, oxytocin. 
nists (22-24). In this field, Yamamura et al. reported an orally effective $\mathrm{V}_{2}$ compound, OPC-31260, exerting aquaresis in several animal models and in man without agonistic activity $(25,26)$

In this study, we describe the structure and the pharmacological properties of SR 121463A, (1-[4-(N-tert-butylcarbamoyl)-2-methoxybenzene sulfonyl]-5-ethoxy-3-spiro-[4-(2-morpho-linoethoxy)cyclohexane]indol-2-one, fumarate), a novel, highly potent and $\mathrm{V}_{2}$-selective nonpeptide AVP receptor antagonist (see Fig. 1). In all the biological tests used, a close comparison was performed between the effects of the two nonpeptide molecules, SR 121463A and OPC-31260, belonging to different chemical series.

In addition, despite the close structural similarities between AVP $\mathrm{V}_{2}$ receptors from different species (7-10), marked differences between their pharmacological properties have been described (21). For these reasons, special attention was paid to the evaluation of SR 121463A in several human tissues and in predictive pharmacological models in order to design a compound devoid of partial agonist effects and with the expected aquaretic activity in man.

\section{Methods}

\section{Materials}

The newly described nonpeptide molecule, SR 121463A, (1-[4-(Ntert-butylcarbamoyl)-2-methoxybenzene sulfonyl]-5-ethoxy-3-spiro[4-(2-morpholinoethoxy)cyclohexane]indol-2-one, fumarate; equatorial isomer), (Fig. 1), was synthesized in Sanofi Recherche, Toulouse, (France) and belongs to an original chemical series of potent and selective $\mathrm{V}_{2}$ receptor antagonists. The only other published nonpeptide $\mathrm{V}_{2}$ receptor antagonist, OPC-31260, $( \pm)$ (5-dimethylamino-1-\{4-(2methylbenzoylamino)benzoyl\}-2,3,4,5-tetrahydro- $1 H$-benzazepine) (24), was synthesized in Sanofi Recherche, (Montpellier, France) and used as a reference in the different biological tests (Fig. 1). The structures of SR 121463A and OPC-31260 were determined by ${ }^{1} \mathrm{H}$ and ${ }^{13} \mathrm{C}$ NMR and infrared spectroscopy. The molecular weights, determined by mass spectrometry, are 736.6 and 427.5 for SR $121463 \mathrm{~A}$ and OPC31260 , respectively. Melting points of 172 and $207.8^{\circ} \mathrm{C}$, respectively, were obtained. The purity, measured by high pressure liquid chromatography, thin layer chromatography and elemental analysis, was $>98 \%$. The analytical parameters reported above for OPC-31260 are identical to those initially described for this molecule (27).

For in vitro experiments, SR 121463A and OPC-31260 were dissolved in DMSO $\left(10^{-2} \mathrm{M}\right)$ and then diluted in the appropriate test solvent. SR 121463A was dissolved in saline and DMF for intravenous and intraperitoneal administration in rats, respectively. For oral treatment, all compounds used were administered in $0.6 \%$ methylcellulose solution.

AVP, polybrene, PMSF, OT, and bacitracin were from Sigma Chemical Co. (L'Isle d'Abeau, France). BSA type V was obtained from IBF (Villeneuve La Garenne, Paris, France). DME and PBS were from Boehringer Mannheim (Meylan, France). All other cell culture reagents were from GIBCO (Life Technologies, GIBCO BRL, France). EDTA, Tris and DMSO were purchased from MerckClevenot (Nogent sur Marne, France). All other chemicals were from Prolabo (Paris, France). SK\&F 101926 (desGly-d $\left(\mathrm{CH}_{2}\right)_{5} \mathrm{D}$ $\operatorname{Tyr}(\mathrm{Et}) \mathrm{VAVP}$ ) (21), used as a reference in the Brattleboro rat experiments, was a generous gift from Dr. L. Kinter. The radioligands, $\left[{ }^{3} \mathrm{H}\right] \mathrm{AVP}(80 \mathrm{Ci} / \mathrm{mmole}),\left[{ }^{125} \mathrm{I}\right] \mathrm{OT}$ antagonist, $\left(\mathrm{d}\left(\mathrm{CH}_{2}\right)_{5} \mathrm{Tyr}(\mathrm{Me})^{2}\right.$, $\left.\left.\mathrm{Thr}^{4}, \mathrm{Orn}^{8}{ }^{[125} \mathrm{I}\right] \mathrm{Tyr}^{9}-\mathrm{NH}_{2}\right) \quad(2,000 \mathrm{Ci} / \mathrm{mmole}),\left[{ }^{3} \mathrm{H}\right] \mathrm{cAMP}(40 \mathrm{Ci} /$ mmole) and $\left[\alpha{ }^{32} \mathrm{P}\right]-\mathrm{ATP}(20 \mathrm{Ci} / \mathrm{mmole})$ were obtained from New England Nuclear, Les Ulis, France. Linear AVP antagonist (Phaa-D$\operatorname{Tyr}(\mathrm{Me})$-Phe-Gln-Asn-Arg-Pro-Arg-Tyr- $\mathrm{NH}_{2}$ ) was iodinated as previously described in (28).

\section{Biological material}

Human tissue samples from adrenals, kidneys, and pituitaries were collected in conformity with the French national ethical rules. Healthy human adrenals were obtained from human donors after brain death. Adrenals were chilled in cold saline and dissected. Crude plasma membranes were prepared within $3-5 \mathrm{~h}$ and stored in liquid nitrogen. Human kidneys were obtained from nephrectromy for renal carcinoma. The tissue was chilled into cold saline and dissected 2-8 h after excision. Only the non pathological part of the kidney was used to prepare crude plasma membranes which were stored in liquid nitrogen. Human pituitary glands were collected from deceased persons within $6 \mathrm{~h}$ after death and immediately stored in liquid nitrogen. Crude plasma membranes were prepared from the frozen tissue before each experiment. Bovine kidneys were obtained from a local slaughterhouse. Mammary tissue was taken from 19-d-old SpragueDawley pregnant rats and stored in liquid nitrogen until used. Male Sprague-Dawley rats, 250--350 g, (Iffa-Credo, Lyon, France) were used for in vitro binding studies and for in vivo activity measurements. Two series of male homozygous Brattleboro rats with central Diabetes Insipidus (DI) weighing 300-350 g, bred in house (INSERM Unité 90, Hôpital Necker, Paris, France) or bought from Harlan Sprague-Dawley (Indianapolis, IN), were used for evaluation of potential agonist antidiuretic activities. All protocols performed in Sanofi Recherche have been approved by the Animal Care and Use Committee of Sanofi Recherche.

\section{In vitro experiments}

Membrane preparations. Human hypophyseal membranes were prepared as previously described in (23). Membrane preparations from human kidneys or adrenal cortex were obtained according to Guillon et al. (29) and (30), respectively. Membranes from $\mathrm{Ltk}^{-}$cells, trans-

\section{SR 121463A}
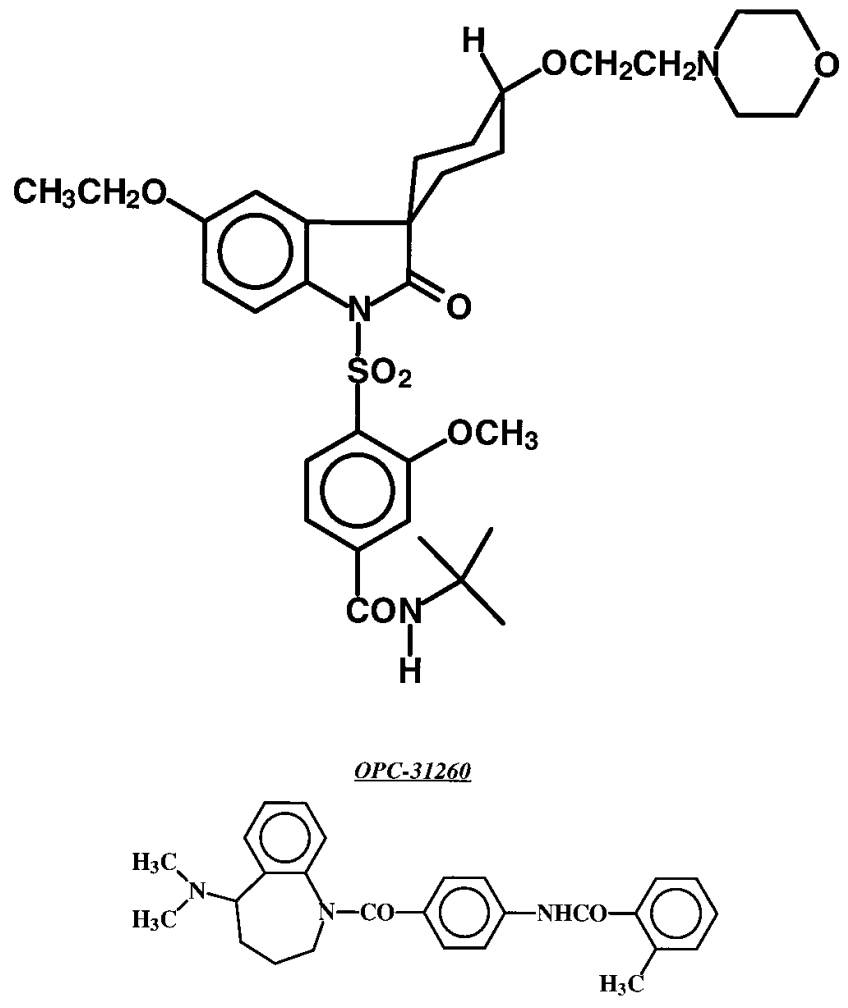

Figure 1. Chemical structure of SR 121463A. (Inset) Structure of OPC-31260 as originally published (24). 
fected with the DNA encoding for the human oxytocin receptor, were prepared as in (31). Briefly, $72 \mathrm{~h}$ after transfection, cells were harvested, washed twice in PBS without $\mathrm{Ca}^{2+}$ and $\mathrm{Mg}^{2+}$, polytron-homogenized in lysis buffer ( $15 \mathrm{mM}$ Tris- $\mathrm{HCl} \mathrm{pH} \mathrm{7.5;2} \mathrm{mM} \mathrm{MgCl} ; 0.3 \mathrm{mM}$ EDTA), and centrifuged at $100 \mathrm{~g}$ for $5 \mathrm{~min}$ at $4^{\circ} \mathrm{C}$. Pellets were washed in a buffer A consisting of $50 \mathrm{mM}$ Tris- $\mathrm{HCl}, \mathrm{pH} 7.4 ; 5 \mathrm{mM}$ $\mathrm{MgCl}_{2}$ and centrifuged at $44,000 \mathrm{~g}$ for $20 \mathrm{~min}$ at $4^{\circ} \mathrm{C}$. Membranes were suspended in a small volume of buffer $\mathrm{A}$ and protein contents were determined. Aliquots of membranes were used immediately or stored at $-80^{\circ} \mathrm{C}$.

Membranes from rat and bovine kidney (papilla and inner medulla), rat liver and rat mammary glands, were prepared according to Stassen et al. (32), Prpic et al. (33) and Serradeil-Le Gal et al. (23), respectively.

Protein concentration was determined by the method of Bradford using bovine serum albumin as a standard (34).

\section{Binding assays}

Binding affinity constants of SR 121463 A and OPC-31260 for the different AVP/OT receptors investigated were deduced from competition experiments using the appropriate radiolabeled ligands: $\left[{ }^{3} \mathrm{H}\right] \mathrm{AVP}$ (bovine and rat kidney, rat liver and human pituitary); $\left[{ }^{125} \mathrm{I}\right]$ linear AVP antagonist (adrenals); [ $\left.{ }^{125} \mathrm{I}\right] \mathrm{OT}$ antagonist (rat mammary glands and $\mathrm{Ltk}^{-}$cells expressing the uterine oxytocin receptor). Experiments were performed as described earlier (23). Binding assays of $\left[{ }^{3} \mathrm{H}\right] \mathrm{AVP}$ to rat kidney medullary membranes were conducted according to the method of Yamamura et al. (24).

For competition experiments, increasing concentrations of SR $121463 \mathrm{~A}$ or OPC-31260 were incubated with membranes and the corresponding ligand under the above-specified conditions. Saturation binding experiments using $\left[{ }^{3} \mathrm{H}\right] \mathrm{AVP}$ (from 0.08 to $20 \mathrm{nM}$ ) as a ligand were performed in bovine kidney in the absence (control) or presence of SR 121463A $(0.25,0.50,1,2$, and $4 \mathrm{nM})$.

\section{Binding data analysis}

The $\mathrm{IC}_{50}$ value was defined as the concentration of inhibitor required to obtain $50 \%$ inhibition of the specific binding. Inhibition constant $\left(K_{\mathrm{i}}\right)$ values were calculated from the $\mathrm{IC}_{50}$ values using the Cheng and Prusoff equation (34). Data for equilibrium binding $\left(K_{\mathrm{d}}, B_{\max }\right)$, competition experiments $\left(\mathrm{IC}_{50}, \mathrm{nHill}\right)$, and kinetic constants $\left(K_{\mathrm{obs}}, K_{-1}\right)$ were analyzed using an iterative non-linear regression program (35). $\mathrm{IC}_{50}$ values of SR $121463 \mathrm{~A}$ and OPC-31260 were compared using Student's $t$ test. Values of $P<0.05$ were taken as significant.

\section{Autoradiography}

Male Sprague-Dawley rats (250-300 g) were killed by decapitation and the kidneys were rapidly removed and frozen in isopentane at $-45^{\circ} \mathrm{C}$. Serial sections $(15 \mu \mathrm{m})$ were cut in a cryostat microtome and thaw-mounted onto chrome alum gelatin-coated glass slides (gelatin $1 \%$, chrome-alum $0.05 \%$ ). Sections were stored at $-80^{\circ} \mathrm{C}$ until use. Slide-mounted sections (3-4 sections/slide), brought to room temperature, were preincubated for $15 \mathrm{~min}$ in the binding buffer $(50 \mathrm{mM}$ Tris- $\mathrm{HCl}, \mathrm{pH} 8.1,2 \mathrm{mM} \mathrm{MgCl} 2,1 \mathrm{mM}$ EDTA, $0.1 \%$ bovine serum albumin and bacitracin). Incubation was carried out for $1 \mathrm{~h}$ at room temperature in the incubating medium in the presence of $2 \mathrm{nM}$ $\left[{ }^{3} \mathrm{H}\right]$ AVP. Nonspecific binding was determined by incubating additional slides under the same conditions and in the presence of $1 \mu \mathrm{M}$ unlabeled AVP. After incubation, the sections were washed three times for 10 min each in ice-cold buffer, dipped briefly in distilled water, and dried under a stream of cold air. Labeled sections were placed on a phosphor-imaging plate (Fuji) for $4 \mathrm{~d}$ and further analyzed with a Bio-Image Analyser (BAS 2000, Fuji) as described in (37).

Adenylyl cyclase assay. Adenylyl cyclase activity was measured as previously described (29) by the rate of conversion of $\left[\alpha-{ }^{32} \mathrm{P}\right] \mathrm{ATP}$ into labeled cyclic AMP. The incubation medium contained: $10 \mathrm{mM}$ sodium azide; $0.1 \mathrm{mM}$ ouabain; $1 \mathrm{mM}$ cAMP; $0.25 \mathrm{mM}$ ATP; 0.17 $\mu \mathrm{Ci} / \mathrm{ml}\left[{ }^{3} \mathrm{H}\right] \mathrm{cAMP} ; 20 \mathrm{mM}$ creatine phosphate; $1 \mathrm{mg} / \mathrm{ml}$ bovine serum albumin and various amounts of the nonpeptide analogues. Membrane proteins, 10-30 $\mu \mathrm{g}$ per assay, were preincubated for $15 \mathrm{~min}$ at $30^{\circ} \mathrm{C}$ and the reaction was initiated by adding ATP $0.25 \mathrm{mM}$ plus 1 $\mu \mathrm{Ci}$ of $\left[\alpha{ }^{3} \mathrm{P}\right] \mathrm{ATP}$ with or without $10 \mathrm{nM}$ AVP. The membranes were incubated for an additional $10 \mathrm{~min}$ period and the reaction stopped by adding $500 \mu \mathrm{l}$ of a solution containing: $100 \mathrm{mM}$ Tris-HCl, pH 8.0; $80 \mathrm{mM}$ sodium dodecylsulfate; $1 \mathrm{mM}$ ATP and $1 \mathrm{mM} \mathrm{cAMP}$. Labeled cAMP was separated and counted by liquid scintillation spectrometry as previously described in (29). All values were corrected for cAMP recovery estimated from the recovery of the $\left[{ }^{3} \mathrm{H}\right] \mathrm{cAMP}$ added to the incubation medium and for a blank value determined in the absence of membranes. Adenylyl cyclase activities were expressed as pmol cAMP accumulated/10 min per mg protein. All determinations were performed in duplicate.

\section{In vivo experiments}

Properties of SR $121463 \mathrm{~A}$ in normally hydrated conscious rats. Male Sprague Dawley rats weighing $290-320 \mathrm{~g}$ were kept in an air-conditioned room at $22 \pm 2^{\circ} \mathrm{C}$ and fed with a standard rat diet (AO4, UAR Epinay sur Orge, France) with water provided ad libitum. In a first set of experiments, SR 121463A was administered intravenously at doses varying from 0.003 to $0.3 \mathrm{mg} / \mathrm{kg}$ (i.e. 0.004 to $0.4 \mu \mathrm{mol} / \mathrm{kg}$ ) body weight $(n=6)$ to normally hydrated conscious rats. SR 121463 A was injected $(1 \mathrm{ml} / \mathrm{kg})$ in $0.9 \% \mathrm{NaCl}$ through a catheter placed in a jugular vein, $48 \mathrm{~h}$ before the experiment. The animals were then housed individually in metabolic cages with water and food ad libitum. Urine was collected for $4 \mathrm{~h}$. In a second set of experiments, SR 121463A, 0.03-10 $\mathrm{mg} / \mathrm{kg}(0.04-14 \mu \mathrm{mol} / \mathrm{kg}, n=7)$, OPC-31260, $10 \mathrm{mg} / \mathrm{kg}(23 \mu \mathrm{mol} / \mathrm{kg}$, $n=8)$, furosemide, $30 \mathrm{mg} / \mathrm{kg}(91 \mu \mathrm{mol} / \mathrm{kg}, n=8)$, hydrochlorothiazide, $30 \mathrm{mg} / \mathrm{kg}(101 \mu \mathrm{mol} / \mathrm{kg}, n=8)$ or vehicle (methylcellulose $0.6 \%$, $n=20)$ were administered orally to rats by gavage $(3 \mathrm{ml} / \mathrm{kg}$ ). After treatment, the rats were placed individually in metabolic cages with food and water ad libitum. Urine was collected throughout the 24-h period after treatment. In the time-course study, the aquaretic effect was measured by collecting urine at $2 \mathrm{~h}$ intervals for $6 \mathrm{~h}$ and then from 6 to $24 \mathrm{~h}$ in control (methylcellulose $0.6 \%, n=20$ ) and treated groups (SR 121463A, 0.03-10 mg/kg p.o., and OPC-31260, $10 \mathrm{mg} / \mathrm{kg}$ ). The effects of the drugs tested on urine osmolality, and urine $\mathrm{Na}^{+}$and $\mathrm{K}^{+}$excretions were tested on a 24-h urine collection period after drug administration. Urine osmolality was measured with a freezing point depression osmometer (model Fisk OS 110, Elvetec, Montpellier, France) and urinary sodium and potassium concentrations with a flame photometer (IL 943, Instrument Laboratories, Marseille, France).

Statistical significance of the results was analyzed by one-way analysis of variance on independent measurements followed by Dunnett or Kruskal-Wallis' test. A two-way analysis of variance followed by Dunnett's test was also used when appropriate.

\section{Activity of SR 121463A in vasopressin-deficient Brattleboro rats} in comparison with the $V_{2}$ peptide antagonist $S K \& F 101926$

The activity of SR 121463 A was compared with that of the reference AVP $V_{2}$ peptide, SK\&F 101926, in an experimental vasopressin-deficient rat strain. Male Brattleboro rats (300-350 g), exhibiting hereditary DI (38), were used in these studies. They were placed in metabolic cages and received food and tap water ad libitum throughout the experiment. After at least seven days of adaptation to the metabolic cages, rats received an i.p. injection of drug or vehicle $(100 \mu \mathrm{l} /$ rat) at $\sim 9: 00 \mathrm{a}$.m. and urine was collected for the next $24 \mathrm{~h}$. Urine volume was measured gravimetrically, and urine osmolality measured with a freezing point osmometer (Roebling, Berlin, Germany). SR $121463 \mathrm{~A}$ was dissolved in dimethylformamide and administered at a dose of $10 \mathrm{mg} / \mathrm{kg}$. The vasopressin analogue, SK\&F 101926, was dissolved in $0.9 \% \mathrm{NaCl}$ and administered at a dose of $0.01 \mathrm{mg} / \mathrm{kg}$. Control rats of each series received the same volume of dimethylformamide or $0.9 \% \mathrm{NaCl}$, respectively. For each drug, control and treated groups were compared by Student's $t$ test. 
Table I. Comparative Affinities of SR 121463A and OPC-31260 for Vasopression and Oxytocin Receptors in Animal and Human Species

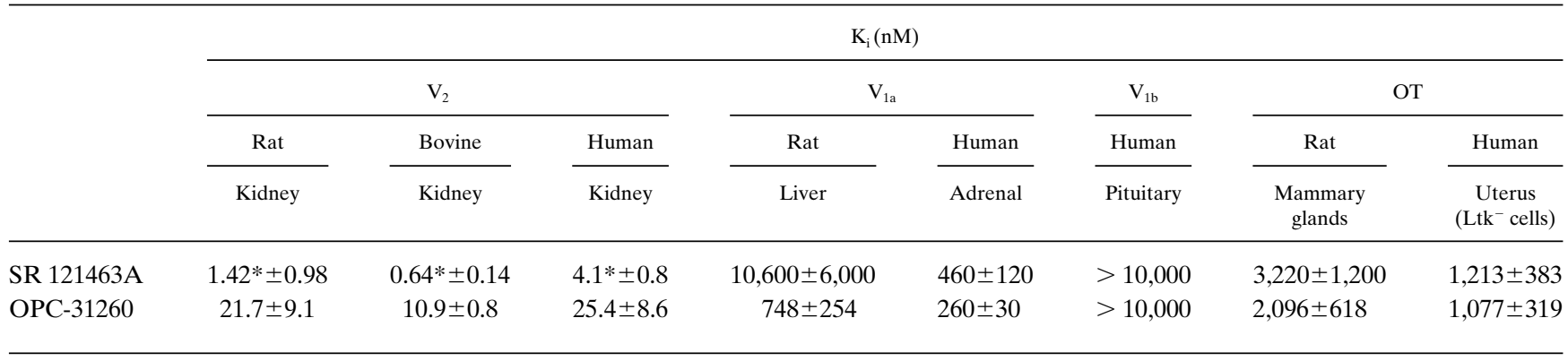

Binding assays were performed as described in Methods. Inhibition constants $\left(K_{\mathrm{i}}\right)$ were determined from competition experiments and calculated according to the equation of Cheng and Prusoff (35). Values are the mean \pm SD of at least three determinations. $\mathrm{V}_{2} \mathrm{IC}_{50}$ values of SR $121463 \mathrm{~A}$ and $\mathrm{OPC}-$ 31260 were compared using Student's $t$ test. Values of $P<0.05$ were taken as significant.

\section{Results}

Interaction of $S R 121463 A$ with animal and human AVP $V_{2}$ receptors, and in vitro selectivity profile. As shown in Table I, SR 121463A displayed a high affinity for AVP $\mathrm{V}_{2}$ receptors from several species including man. This nonpeptide compound dose-dependently inhibited $\left[{ }^{3} \mathrm{H}\right] \mathrm{AVP}$ specific binding to kidney medullo-papillary membranes from rat, bovine and human origin with a Hill coefficient close to the unity, compatible with a single site competitive model as illustrated in human kidney membranes (Fig. $2 A$ ).

Moreover, saturation binding experiments performed in a bovine kidney preparation in the absence or presence of SR $121463 \mathrm{~A}(0.25,0.50,1,2$, and $4 \mathrm{nM})$ confirmed that this compound interacted competitively with renal AVP $V_{2}$ receptors. Indeed, in the presence of this molecule, the apparent dissociation constant $\left(K_{\mathrm{d}}\right)$ was dose-dependently decreased, whereas the maximal binding capacity $\left(B_{\max }\right)$ was not significantly modified (Fig. 3). The $K_{\mathrm{i}}$ value calculated from Scatchard plots
$(0.78 \pm 0.15 \mathrm{nM})$ was consistent with that obtained according to the Cheng and Prusoff equation in competition experiments performed in bovine kidney preparations $\left(K_{\mathrm{i}}=0.87 \mathrm{nM}\right)$.

In terms of selectivity, the highly $\mathrm{V}_{2}$-specific profile of $\mathrm{SR}$ 121463A was firstly evidenced for other AVP receptor subtypes $\left(\mathrm{V}_{1 \mathrm{a}}, \mathrm{V}_{1 \mathrm{~b}}\right)$ and for the closely related oxytocin (OT) receptor from both animal and human origin. As shown in Table I, SR 121463A exhibited only weak affinities for other AVP/ OT receptors and interacted with at least a 100 fold lower potency with $\mathrm{V}_{1 \mathrm{a}}, \mathrm{V}_{1 \mathrm{~b}}$, and OT receptors than with $\mathrm{V}_{2}$. Second, the high degree of specificity of SR 121463A for the $V_{2}$ receptor was further demonstrated in several additional binding assays $(n=50)$ showing that SR $121463 \mathrm{~A}(1 \mu \mathrm{M})$ was unable to bind to a variety of receptors of nonpeptide (histamine, adrenergic, dopamine, serotonin, adenosine, L-type calcium channel, benzodiazepine) or peptide ligands (angiotensin II, endothelin, neuropeptide $\mathrm{Y}$, cholecystokinin, CRF, neurotensin) (not shown).

The comparison with the nonpeptide compound, OPC-
(A)

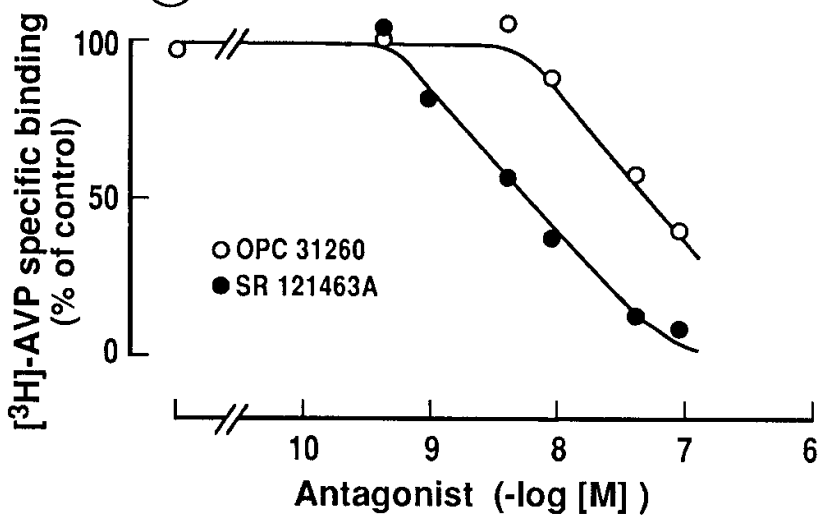

(B)

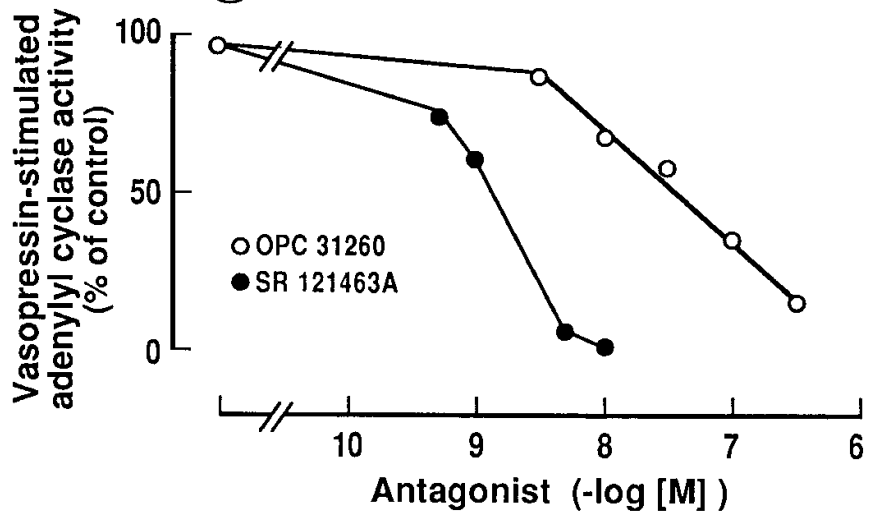

Figure 2. Effect of SR 121463A on binding to AVP $\mathrm{V}_{2}$ receptors $(A)$ and on AVP-stimulated adenylyl cyclase activity $(B)$ in human kidney membranes. Comparison with OPC-31260. Binding assays were performed for $60 \mathrm{~min}$ at $37^{\circ} \mathrm{C}$ in the presence of $\left.1 \mathrm{nM} \mathrm{[}{ }^{3} \mathrm{H}\right] \mathrm{AVP}, 10-30 \mu \mathrm{g}$ of membranes and increasing concentrations of SR 121463A or OPC-31260. Nonspecific binding was determined by adding $1 \mu \mathrm{M}$ unlabeled AVP in the incubating medium. Specific binding is the difference between total and nonspecific binding, and is expressed as percentage of specific binding determined without drug $\left(100 \%=13 \pm 4\right.$ fentomoles of $\left[{ }^{3} \mathrm{H}\right] \mathrm{AVP}$ specifically bound $/ \mathrm{mg}$ protein $)$. For adenylyl cyclase activity, AVP 10 $\mathrm{nM}$ or vehicule (basal) and $\left[\alpha{ }^{32} \mathrm{P}\right]-\mathrm{ATP}$ were added in the assay for $10 \mathrm{~min}$ at $30^{\circ} \mathrm{C}$. $\left[{ }^{32} \mathrm{P}\right] \mathrm{cAMP}$ generated was then determined as described under Methods. Results are expressed as percent of cAMP generated by $10 \mathrm{nM}$ AVP minus basal for control $(100 \%=41 \pm 2 \mathrm{picomoles} \mathrm{cAMP} / 10$ $\mathrm{min} / \mathrm{mg}$ protein). Results are the mean of duplicate determinations from a single experiment representative of three. 


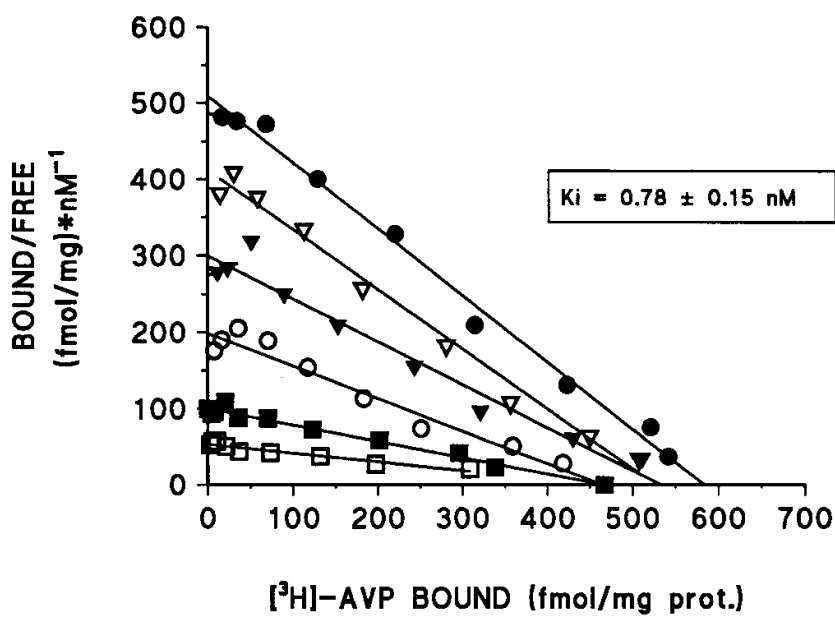

Figure 3. Scatchard plots of $\left[{ }^{3} \mathrm{H}\right] \mathrm{AVP}$ binding to bovine kidney membranes without $(\mathbf{O})$ or with $0.25(\nabla), 0.5(\boldsymbol{\nabla}), 1(\bigcirc), 2(\mathbf{\square})$, and $4(\square)$ nM SR 121463A. Results represent data from a typical experiment. All experiments were performed in duplicate.

31260, tested under similar experimental conditions, showed that this molecule displayed significantly lower affinity (6 to 17fold) than SR 121463A for AVP $V_{2}$ receptors in the different species tested (Table I, Fig. $2 A$ ). The affinity found here for OPC-31260 both in rat kidney and liver membranes is in agreement with the original published values (24). In addition, OPC-31260 showed only a relatively weak specificity for $\mathrm{V}_{2}$ receptors since this molecule also exhibited significant affinity for AVP $\mathrm{V}_{1 \mathrm{a}}$ receptors especially in human tissues (Table I). The selectivity index of SR 121463A and OPC-31260 for the human $\mathrm{V}_{2}$ receptor versus the human $\mathrm{V}_{1 \mathrm{a}}, \mathrm{V}_{1 \mathrm{~b}}$, and OT receptors clearly evidenced a better specificity for SR 121463A
Table II. Selectivity Profile of the Two Nonpeptide AVP $V_{2}$ Receptor Antagonists, SR 121463A and OPC-31260, for Human Vasopressin and Oxytocin Receptors

\begin{tabular}{lccc}
\hline & \multicolumn{3}{c}{ Selectivity index } \\
\cline { 2 - 4 } & $K_{\mathrm{i}} \mathrm{V}_{1 \mathrm{a}} / K_{\mathrm{i}} \mathrm{V}_{2}$ & $K_{\mathrm{i}} \mathrm{V}_{1 \mathrm{~b}} / \mathrm{K}_{\mathrm{i}} \mathrm{V}_{2}$ & $K_{\mathrm{i}} \mathrm{OT} / K_{\mathrm{i}} \mathrm{V}_{2}$ \\
\hline SR 121463A & 112 & $>2400$ & 296 \\
OPC-31260 & 10 & $>390$ & 42 \\
\hline
\end{tabular}

Inhibition constants $\left(K_{\mathrm{i}}\right)$ used in the calculation of these ratios are given in Table I.

(> 100) (Table II) showing that OPC-31260 should rather be considered as a $\mathrm{V}_{2} / \mathrm{V}_{1 \text { a }}$ compound, whereas SR $121463 \mathrm{~A}$ is the first potent and highly selective nonpeptide $V_{2}$ ligand yet described.

Autoradiographic localization of $A V P V_{2}$ receptors in the rat kidney using SR 121463A. Autoradiographic experiments, using $\left[{ }^{3} \mathrm{H}\right] \mathrm{AVP}$ as a ligand, provided the mapping and localization of AVP receptors in the rat kidney. As illustrated in Fig. 4 $A,\left[{ }^{3} \mathrm{H}\right] \mathrm{AVP}$ intensively labeled the medullo-papillary region of the kidney and, to a lesser extent, the cortex, as previously described $(39,40)$. SR 121463A $(100 \mathrm{nM})$ displaced most of $\left[{ }^{3} \mathrm{H}\right] \mathrm{AVP}$ labeling in the medullo-papillary area (Fig. $4 \mathrm{C}$ ). The remaining amounts of labeling observed, particularly in the region of the medulla, in the pelvic wall and in the cortex could be due to $\left[{ }^{3} \mathrm{H}\right] \mathrm{AVP}$ binding to $\mathrm{V}_{1 \mathrm{a}}$ receptors also present in this organ $(37,40)$. At the same $100 \mathrm{nM}$ concentration, OPC-31260 appears to be less potent than SR 121463A in displacing [ $\left.{ }^{3} \mathrm{H}\right]$ AVP labeling in rat kidney sections (Fig. $4 D$ ), as expected according to the affinity in rat kidney membranes observed for OPC-31260, almost 20-fold lower than for SR 121463A (Table
A
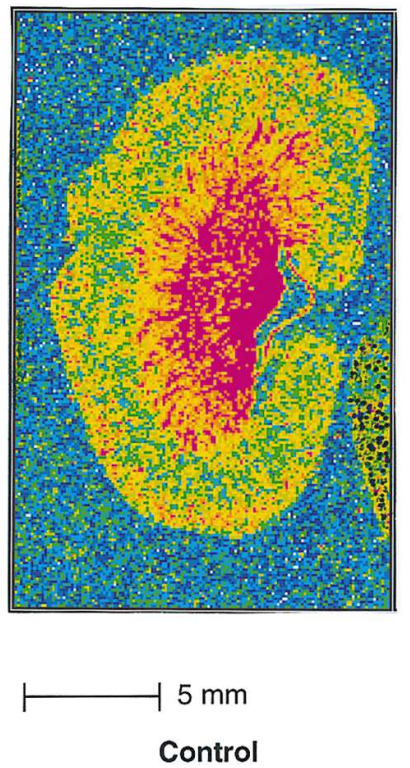

Control
B

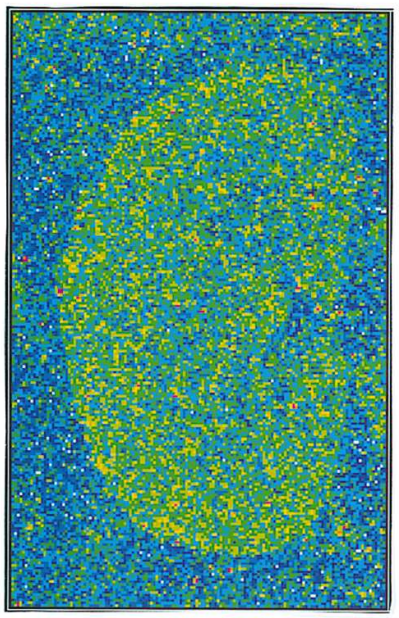

C

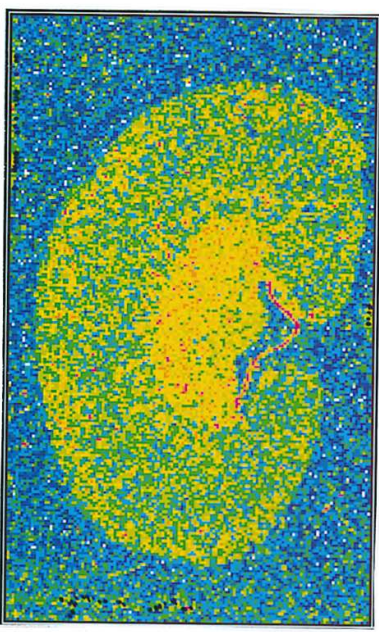

Intensity of labeling

Non specific

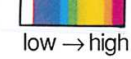

SR 121463A

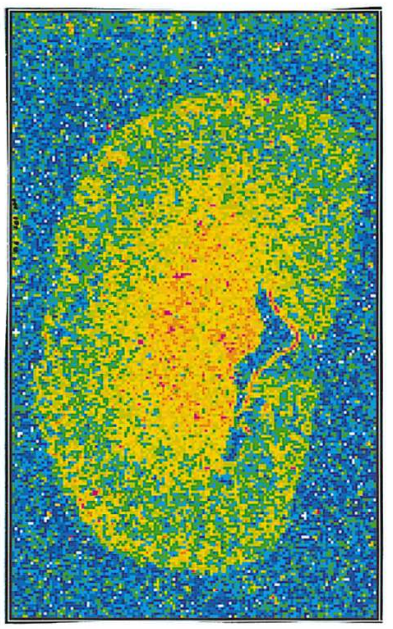

OPC-31260

Figure 4. Autoradiograms of $\left[{ }^{3} \mathrm{H}\right] \mathrm{AVP}$ binding to rat kidney sections in the absence $(A)$ or presence of $1 \mu \mathrm{M}$ AVP $(B), 0.1 \mu \mathrm{M} \mathrm{SR} 121463 \mathrm{~A}(C)$, or $0.1 \mu \mathrm{M}$ OPC-31260 $(D)$. The nonspecific binding $(B)$ was obtained by incubating alternate sections in the presence of $1 \mu \mathrm{M}$ unlabeled AVP. The scale in $A$ represents $5 \mathrm{~mm}$. 

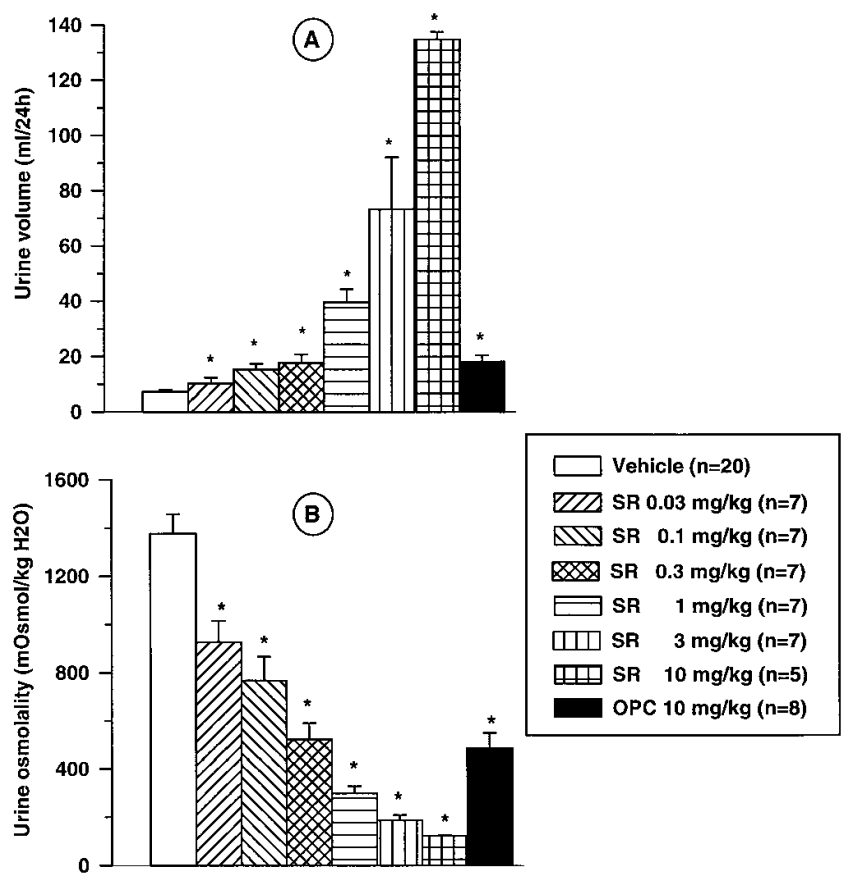

Figure 5. Effects of SR $121463 \mathrm{~A}$ on cumulative urine volume $(A)$ and urine osmolality $(B)$ after oral administration $(0.03-10 \mathrm{mg} / \mathrm{kg}$, i.e. $0.04-14 \mu \mathrm{mol} / \mathrm{kg}$ ) in conscious rats. Comparison with OPC-31260, 10 $\mathrm{mg} / \mathrm{kg}(23 \mu \mathrm{mol} / \mathrm{kg})$ p.o. Urine was collected for $24 \mathrm{~h}$ after SR $121463 \mathrm{~A}$ (SR) or OPC-31260 (OPC) administration in a $0.6 \%$ methylcellulose solution. Values are means \pm SEM of 5-20 determinations per group. Statistical analysis was performed using a Kruskall-Wallis' test and the level of significance was taken as $P<0.05$ for comparison with the control.

I). Thus, SR 121463A represents a selective $V_{2}$ probe for studying the in situ localization of $\mathrm{V}_{2}$ receptors.

Effect of SR 121463A on adenylyl cyclase activity in human kidney membranes. To determine the agonist or antagonist properties of SR 121463A, we examined the activity of this compound on the AVP-induced adenylyl cyclase activity in human kidney membranes. In these preparations, AVP maximally stimulated cAMP production by $3.6 \pm 0.3$-fold with a $K_{\text {act }}$ of $2.5 \mathrm{nM}$ (data not shown) in good agreement with previous results (29). Data shown in Fig. 2 B demonstrate that both SR 121463A and OPC-31260 dose-dependently inhibited AVP (10 $\mathrm{nM}$ )-induced adenylyl cyclase stimulation yielding respective $K_{\mathrm{i}}$ values of $0.26 \pm 0.04$ and $17.6 \pm 8.3 \mathrm{nM}(n=3)$. These results clearly evidenced a higher potency of SR 121463A versus OPC-31260 in inhibiting AVP-stimulated adenylyl cyclase, as expected from the binding affinities found for these two compounds for the human kidney $\mathrm{V}_{2}$ receptors (Fig. $2 \mathrm{~A}$ ). Moreover, neither SR 121463A nor OPC-31260 were able to stimulate the basal adenylyl cyclase activity in human kidney membranes in concentrations up to $100 \mu \mathrm{M}$, showing the total absence of agonistic properties (not shown).

In vivo activity of $S R 121463$ A in normal conscious rats. In normally hydrated conscious rats, oral administration of SR 121463A, $0.03-10 \mathrm{mg} / \mathrm{kg}(0.04-14 \mu \mathrm{mol} / \mathrm{kg})$, increased urine excretion and decreased urine osmolality dose-dependently (Fig. 5). This effect was significant from $0.03 \mathrm{mg} / \mathrm{kg}$ on urine osmolality and from $0.1 \mathrm{mg} / \mathrm{kg}$ and upwards for urine volume $(P<0.05)$. The time-course showed a rapid effect on urine

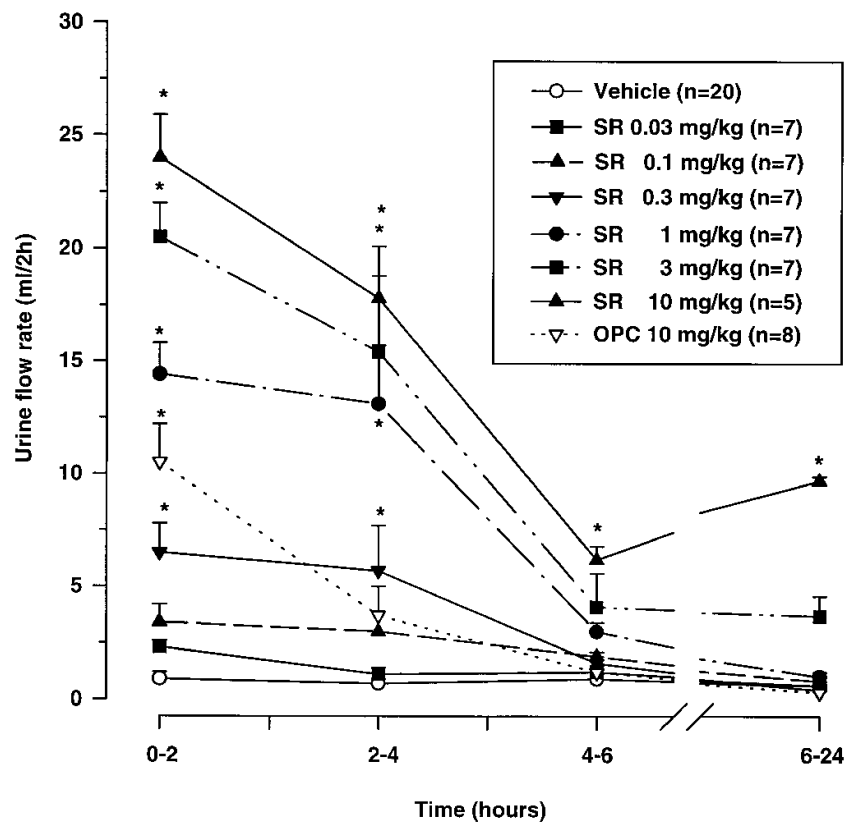

Figure 6. Time-course study of SR $121463 \mathrm{~A}$ action on urine flow rate after oral administration $(0.03-10 \mathrm{mg} / \mathrm{kg})$ in conscious rats. Comparison with OPC-31260, $10 \mathrm{mg} / \mathrm{kg}$ p.o. Urine was collected throughout the 24 -h period after treatment. The aquaretic effect was measured by collecting urine at 2-h intervals for $6 \mathrm{~h}$ and then from 6 to $24 \mathrm{~h}$ in control (methylcellulose $0.6 \%, n=20)$ and treated groups $(0.03-10$ $\mathrm{mg} / \mathrm{kg}$ i.e. 0.04 to $14 \mu \mathrm{mol} / \mathrm{kg}$ p.o. for SR $121463 \mathrm{~A}$ (SR) and $10 \mathrm{mg} / \mathrm{kg}$ $(23 \mu \mathrm{mol} / \mathrm{kg})$ p.o. for OPC-31260 (OPC)). The value of the timeperiod 6-24 h was also averaged per $2 \mathrm{~h}$. Values are mean \pm SEM of 5 to 20 determinations per group. Statistical analysis was performed using a two-way analysis of variance followed by Dunnett's test, and the level of significance was taken as $P<0.05$ for comparison with the control.

flow rate. The maximal effect was reached during the first 2 hour-period after the administration of the different doses of SR 121463A (Fig. 6). The higher doses (3 and $10 \mathrm{mg} / \mathrm{kg}$ ) had effects lasting into the 6-24 h sampling period as shown by a urine flow rate higher than that occurring in the vehicletreated group. Under identical experimental conditions, OPC$31260,10 \mathrm{mg} / \mathrm{kg}(23 \mu \mathrm{mol} / \mathrm{kg})$ p.o., was equipotent to $\mathrm{SR}$ 121463A, 0.3-1 mg/kg (0.4-1.4 $\mu \mathrm{mol} / \mathrm{kg})$ p.o., on the drop in urine osmolality and on the increase in $24 \mathrm{~h}$ collected urine, in agreement with the lower $\mathrm{V}_{2}$ receptor affinity found for OPC31260 in rat kidney membranes (Table I).

Intravenous administration of SR 121463A from 0.003 to $0.3 \mathrm{mg} / \mathrm{kg},(0.004-0.4 \mu \mathrm{mol} / \mathrm{kg})$, induced a dose-dependent increase in urine flow rate which was exactly parallel to the oral dose-response curve (Fig. 7). From these plots, a ratio of 5 between intravenous and oral efficacies could be deduced ( 0.1 $\mathrm{mg} / \mathrm{kg}[0.14 \mu \mathrm{mol} / \mathrm{kg}]$ i.v. induced similar effect to $0.5 \mathrm{mg} / \mathrm{kg}$ [6.8 $\mu \mathrm{mol} / \mathrm{kg}]$ p.o.) demonstrating good oral bioavailability for SR 121463A.

Table III further summarizes the effects of SR 121463A on urine flow rate, osmolality and $\mathrm{Na}^{+} / \mathrm{K}^{+}$excretion in comparison with those of traditional diuretic compounds such as furosemide and hydrochlorothiazide. These agents were used at oral doses eliciting similar effects on urine volume excretion $(0.3 \mathrm{mg} / \mathrm{kg}$ i.e. $0.4 \mu \mathrm{mol} / \mathrm{kg}$ for SR $121463 \mathrm{~A}, 30 \mathrm{mg} / \mathrm{kg}$ for furo- 


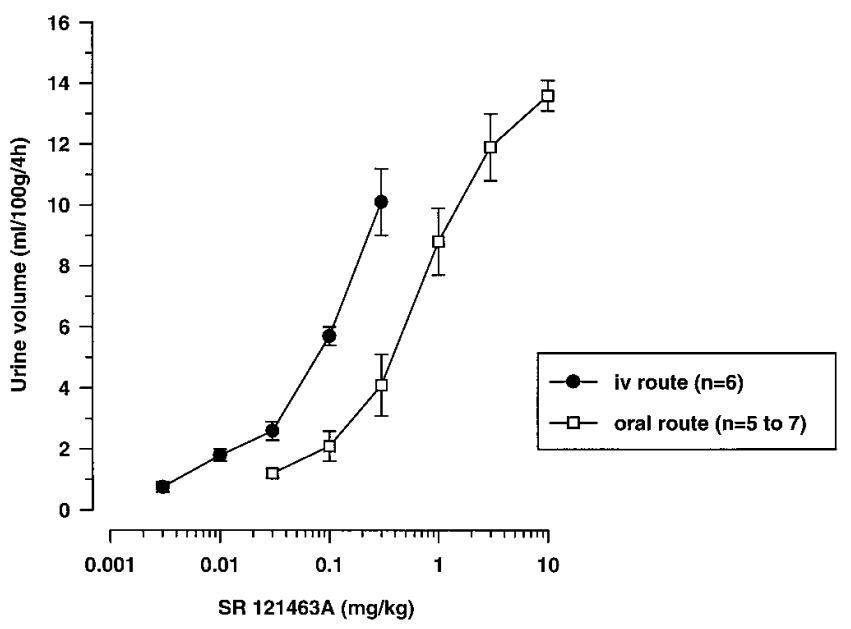

Figure 7. Comparison of intravenous and oral administration of SR $121463 \mathrm{~A}$ on urine flow rate in normally-hydrated conscious rats. Dose-response curves were obtained after i.v. injection of SR $121463 \mathrm{~A}$ in isotonic saline and after p.o. administration in a $0.6 \%$ methylcellulose solution. Data are expressed as means \pm SEM of 5 to 7 determinations per group.

semide $(91 \mu \mathrm{mol} / \mathrm{kg})$ and hydrochlorothiazide $(101 \mu \mathrm{mol} / \mathrm{kg})$. At this oral dose, SR 121463A caused an increase in urine volume and a drop in urine osmolality with no significant change $(P>0.05)$ in $\mathrm{Na}^{+}$and $\mathrm{K}^{+}$excretion over a 24 -h period (Table III). Furosemide and hydrochlorothiazide, $30 \mathrm{mg} / \mathrm{kg}$ p.o., induced roughly similar effects to SR $121463 \mathrm{~A}, 0.3 \mathrm{mg} / \mathrm{kg}$, on urine flow rate and osmolality but, as well-known for classical diuretic/saliuretic agents, the urine $\mathrm{Na}^{+}$excretion was markedly increased (Table III). It is important to note that hydrochlorothiazide, studied during a 24 hour period, induced a strong effect on both urine $\mathrm{Na}^{+}$and $\mathrm{K}^{+}$excretion.

Thus, SR 121463A is the most potent orally-effective $\mathrm{V}_{2}$ antagonist i.e. aquaretic agent yet described. It is devoid of the effects of traditional diuretic agents on solute excretion $\left(\mathrm{Na}^{+}\right.$ and/or $\mathrm{K}^{+}$loss).

Activity of SR 121463 A in vasopressin-deficient Brattleboro rats in comparison with $S K \& F 101926$. SK\&F 101926, a promising peptide $\mathrm{V}_{2}$ receptor antagonist with a powerful aquaretic effect in several animal species and models, turned out to be a partial $\mathrm{V}_{2}$ agonist with potent antidiuretic properties when tested in man. In fact, the partial agonistic properties of this compound could also be detected in the vasopressin-deficient Brattleboro rat strain because these rats have higher sensitivity to antidiuretic agonists than AVP-repleted rats $(21,41,42)$. These findings suggest that this experimental model allows the assessment of the partial agonistic activities of putative aquaretic agents. We studied the influence of SR 121463A in comparison with SK\&F 101926 on urine excretion and osmolality in these rats (Fig. 8). As expected, control Brattleboro rats, exhibiting hereditary central DI, were characterized by a high urine flow rate $(\sim 200 \mathrm{ml} / 24 \mathrm{~h})$ and low urine osmolality $(\sim 170$ $\left.\mathrm{mOsm} / \mathrm{kg} \mathrm{H} \mathrm{H}_{2} \mathrm{O}\right)$. As shown in Fig. 8, SR 121463A $(10 \mathrm{mg} / \mathrm{kg}$ i.p.) induced significant aggravation of these parameters by further enhancing urine flow rate by $77 \%(354 \pm 42 \mathrm{ml} / 24 \mathrm{~h})$ and lowering urinary osmolality by $54 \%(92 \pm 8 \mathrm{mOsm} / \mathrm{kg}$ $\left.\mathrm{H}_{2} \mathrm{O}\right)(P<0.01)$. In contrast, $\mathrm{SK} \& \mathrm{~F} 101926$ induced antidiuretic effects in this model by lowering urine volume and increasing urine osmolality by $60 \%$ each, as previously described. It is important to note that further experiments, performed with increasing concentrations of SR 121463A, have shown that the effects observed on urine volume and osmolality in DI rats are dose-dependent and are detectable with doses as low as $0.01 \mathrm{mg} \mathrm{kg}$ i.p. (data not shown). In conclusion, SR 121463A appears to be devoid of any antidiuretic properties even when administered at a high dose in Brattleboro rats. Moreover, this molecule is able to enhance diuresis in this animal model.

\section{Discussion}

Specific blockade of renal AVP $\mathrm{V}_{2}$ receptors seems to be a relevant approach for generating selective aquaretic agents for the treatment of water-retaining disorders (15-20). Therefore, intensive work and active investigations have been performed to design selective ligands for AVP receptors (22-24, 43). The present study describes the biochemical and pharmacological profile of SR 121463A, a newly potent and selective nonpeptide AVP $V_{2}$ receptor antagonist with powerful oral aquaretic properties in the rat.

This new molecule (Fig. 1), belonging to an original chemical series, shows high affinity and marked selectivity for AVP $\mathrm{V}_{2}$ receptors from animal and human origin (Table $\mathrm{I}$ ). In binding experiments, SR 121463A inhibits [ $\left.{ }^{3} \mathrm{H}\right] \mathrm{AVP}$ labeling to rat, bovine and human kidney membranes with nanomolar and even subnanomolar potency ( $K_{\mathrm{i}}$ values of $1.42,0.64$, and 4.1 $\mathrm{nM}$, respectively). As demonstrated in bovine kidney preparations, SR 121463A is a full competitive inhibitor (Fig. 3). Since

Table III. Effects of SR 121463A, Furosemide and Hydrochlorothiazide p.o. on Urine Volume and Osmolality, and on Na and $\mathrm{K}^{+}$ Urinary Excretion in Normally Hydrated Rats

\begin{tabular}{lcccc}
\hline & Control & SR $121463 \mathrm{~A}$ & Furosemide & Hydrochlorothiazide \\
\hline & & $0.3 \mathrm{mg} / \mathrm{kg}$ & $30 \mathrm{mg} / \mathrm{kg}$ & $30 \mathrm{mg} / \mathrm{kg}$ \\
Urine volume $(\mathrm{ml} / 24 \mathrm{~h})$ & $7.1 \pm 0.7$ & $17.8 \pm 3^{*}$ & $16.1 \pm 1.3^{*}$ & $14.9 \pm 1.1^{*}$ \\
$\quad$ Urine osmolality & $1,308 \pm 73$ & $524 \pm 67^{*}$ & $613 \pm 37^{*}$ & $798 \pm 32^{*}$ \\
$\quad(\mathrm{mOsmol} / \mathrm{kg} \mathrm{H} \mathrm{O})$ & $912 \pm 63$ & & & \\
$\mathrm{Na}^{+}(\mu \mathrm{mol} / 24 \mathrm{~h})$ & $1,464 \pm 95$ & $1,026 \pm 100$ & $1,276 \pm 69^{*}$ & $1,727 \pm 150^{*}$ \\
$\mathrm{~K}^{+}(\mu \mathrm{mol} / 24 \mathrm{~h})$ & & $1,410 \pm 87$ & $1,680 \pm 109$ & $2,047 \pm 168^{*}$ \\
& & &
\end{tabular}

Control were treated with $0.6 \%$ methylcellulose as described in the Methods section. Groups of 7-8 animals were treated with oral SR $121463 \mathrm{~A}$ ( 0.3 $\mathrm{mg} / \mathrm{kg}$, i.e., $0.4 \mu \mathrm{mol} / \mathrm{kg})$, furosemide $(30 \mathrm{mg} / \mathrm{kg}$, i.e., $91 \mu \mathrm{mol} / \mathrm{kg})$ or hydrochlorothiazide $(30 \mathrm{mg} / \mathrm{kg}$, i.e., $101 \mu \mathrm{mol} / \mathrm{kg})$ and urines were collected for $24 \mathrm{~h}$ after drug or vehicle administration. Statistical significance was assessed by Dunnett or Kruskal-Wallis' test: * $P<0.05$. 

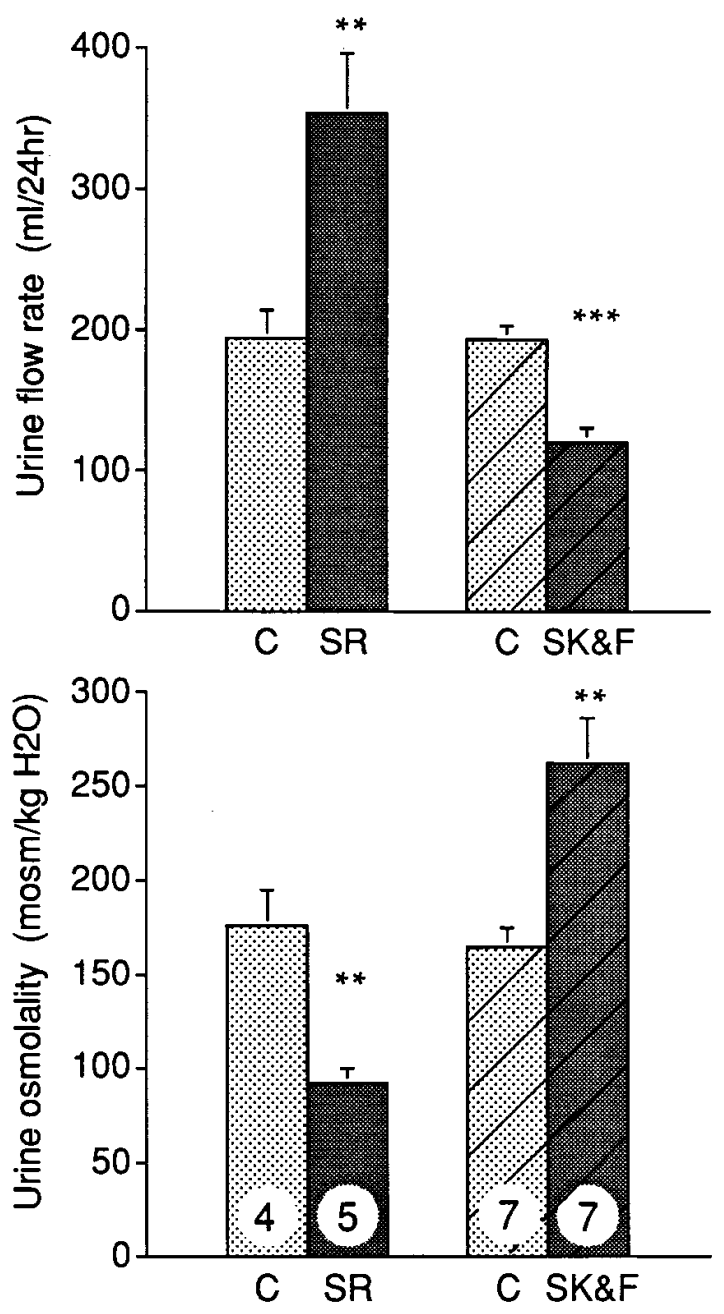

Figure 8. Effect of acute i.p. administration of SR 121463A and SK\&F 101926 on urinary flow rate and osmolality in Brattleboro rats. SR 121463A $(S R): 10 \mathrm{mg} / \mathrm{kg}$ dissolved in dimethylformamide. SK\&F $101926(S K \& F): 0.01 \mathrm{mg} / \mathrm{kg}$ dissolved in $0.9 \% \mathrm{NaCl}$. For each antagonist, drug and control groups were compared by Student's $t$ test: $* * P<0.01, * * * P<0.001$. Values are means \pm SEM. Number of rats receiving the drug (SR or SK\&F) or vehicle $(C)$ are shown in white circles in each bar.

we $(23,44)$, and others $(29,45,46)$, have previously demonstrated marked species differences in the in vitro affinity and potency of several nonpeptide AVP/OT receptor antagonists, especially when tested in human tissues, it is of importance to underline that SR 121463A also potently interacts with human renal $\mathrm{V}_{2}$ receptors. Moreover, the high affinity of SR 121463A found in this latter preparation is consistent with the powerful antagonist effect of this compound in inhibiting AVP-stimulated adenylyl cyclase $\left(K_{\mathrm{i}}\right.$ value of $\left.0.26 \mathrm{nM}\right)$ without any agonistic response (Fig. 2).

Another striking finding is the high degree of selectivity of SR 121463A for AVP $V_{2}$ receptors as evidenced in several binding tests in vitro. Firstly, this compound has very low affinity for AVP $V_{1 a}, V_{1 b}$ and for the related oxytocin receptors (selectivity index at least $>100$; Table II) and secondly, SR $121463 \mathrm{~A}$ does not interact with more than 50 receptors of other nonpeptide or peptide ligands. It is noteworthy that de- spite the low affinity of SR $121463 \mathrm{~A}$ for $\mathrm{V}_{1 \mathrm{a}}$ receptors, this molecule is able to discriminate rat liver and human adrenal $\mathrm{V}_{\text {1a }}$ receptors (Table I).

When the properties of OPC-31260, the only other published nonpeptide $\mathrm{V}_{2}$ receptor antagonist, and SR $121463 \mathrm{~A}$ are compared under similar experimental conditions, OPC-31260 is significantly less potent $\left(K_{\mathrm{i}}>10 \mathrm{nM}\right.$ versus $K_{\mathrm{i}}$ in the nanomolar range for SR 121463) in inhibiting [ $\left.{ }^{3} \mathrm{H}\right] \mathrm{AVP}$ binding to rat, bovine and human kidney membranes and in antagonizing AVP-stimulated adenylyl cyclase in human kidney plasma membranes in vitro (Table I and Fig. 2). Moreover, SR $121463 \mathrm{~A}$ is much more selective towards the $\mathrm{V}_{2} \mathrm{AVP}$ receptor subtype than OPC-31260 (Table II). Indeed, despite a wellconserved affinity of OPC-31260 for human $\mathrm{V}_{2}$ receptors, this compound exhibits a poor $\mathrm{V}_{2}$ selectivity profile especially noticeable on human AVP and OT receptors (Tables I and II). These data are consistent with previous results showing a significant interaction of OPC-31260 with human $\mathrm{V}_{1 \mathrm{a}}$ receptors, both in binding (44) and functional studies. In vitro, OPC31260 effectively antagonizes AVP-induced contractions in human isolated internal mammary and coronary arteries (47, 48), known to express the AVP $\mathrm{V}_{1 \mathrm{a}}$ receptor subtype. Thus, this molecule could be considered as a $V_{2} / V_{1 a}$ antagonist compound whereas SR $121463 \mathrm{~A}$ is a pure $\mathrm{V}_{2}$ ligand.

In addition, autoradiographic experiments performed in rat kidney sections, using $\left[{ }^{3} \mathrm{H}\right] \mathrm{AVP}$ as the ligand and SR 121463A, show an intense localization of $V_{2}$ binding sites specifically in the medullo-papillary region of the kidney in agreement with previous reports using mRNA $\mathrm{V}_{2}$ receptor in situ hybridization and autoradiographic techniques $(39,40)$. Indeed, SR $121463 \mathrm{~A}$ is the most $\mathrm{V}_{2}$ selective ligand so far described. Thanks to its high stability, it may represent a good pharmacological tool for mapping $\mathrm{V}_{2}$ receptors in the organism and for the search of extrarenal $V_{2}$ sites (49) and/or potential $V_{2}$ subtypes. In that respect, a $\mathrm{V}_{2}$ receptor subtype has been suggested in rat limbic brain areas (50) and $\mathrm{V}_{2}$ receptor mRNA has also been detected in rat hippocampus (51).

The pharmacological profile of SR 121463A described herein deserves to be underlined and demonstrates that this molecule is a potent fully aquaretic drug in several rat experimental models in vivo. After intravenous and oral administration in normally hydrated rats, SR 121463A enhanced the urine flow rate and decreased urine osmolality in a dose-dependent manner showing that SR 121463A is able to counteract the antidiuretic effect of endogenous vasopressin. The comparison between intravenous and oral responses shows that SR $121463 \mathrm{~A}$ is well absorbed (oral route only 5 times less potent than i.v. route) and has good bioavailibility. The diuretic effect, and the subsequent drop in urine osmolality, at $0.3 \mathrm{mg} / \mathrm{kg}$ $(0.4 \mu \mathrm{mol} / \mathrm{kg})$ p.o., are almost equipotent to those of oral OPC-31260, $10 \mathrm{mg} / \mathrm{kg}(23 \mu \mathrm{mol} / \mathrm{kg})$, and furosemide $30 \mathrm{mg} / \mathrm{kg}$ (91 $\mu \mathrm{mol} / \mathrm{kg})$ or hydrochlorothiazide $30 \mathrm{mg} / \mathrm{kg}(91 \mu \mathrm{mol} / \mathrm{kg})$. Moreover, the comparison of SR 121463A with these two classical diuretics on urine parameters clearly evidences different pharmacological profiles due to the different intrinsic mechanisms of action of these drugs (Table III). Furosemide and hydrochlorothiazide elicit a well-known effect on $\mathrm{Na}^{+}$and/or $\mathrm{K}^{+}$ excretion, associated with water excretion, whereas SR 121463A has a pure aquaretic effect. In fact, the interaction of AVP $V_{2}$ antagonists with the renal $V_{2}$ receptors has been shown to prevent AVP-induced insertion of specific water channels (recently cloned aquaporin 2, AQP2) into the luminal membrane 
and thus, to specifically block water reabsorption in collecting duct cells $(52,53)$. This original mechanism of action highlights the interest of such molecules in several diseases in which water retention is closely associated with hypotonic hyponatremia.

Another important question raised with AVP $V_{2}$ receptor antagonists is partial agonist antidiuretic activity, in some of the species investigated. The problem encountered by SK\&F researchers with peptide $V_{2}$ antagonists illustrates the difficulty of designing effective aquaretic agents in man. One of these peptides, SK\&F 101926, was identified as a potent aquaretic agent in rats, dogs and squirrel monkeys and was the most potent $\mathrm{AVP} \mathrm{V}_{2}$ analogue in inhibiting AVP-stimulated adenylyl cyclase in vitro in all these species. But this promising molecule turned out to be a potent antidiuretic agent in man during clinical trials. Interestingly, SK\&F 101926 disclosed significant agonist effects in Brattleboro rats when injected at a dose which induced marked diuresis in normal rats $(21,41,42)$. Therefore, despite the potent inhibitory effect of SR 121463A on AVPstimulated adenylyl cyclase and the lack of an agonistic effect (at concentrations up to $100 \mu \mathrm{M}$ ) in this preparation, we further investigated SR 121463A in the vasopressin-deficient Brattleboro rat strain which seems to be a predictive and sensitive pharmacological model for detecting antidiuretic activity. Experiments performed in Brattleboro rats reveal that SR $121463 \mathrm{~A}$ is devoid of any $\mathrm{V}_{2}$ agonistic effect, even when administered at a high dose $(10 \mathrm{mg} / \mathrm{kg}$ i.p. $)$. Moreover, in this experimental model, this selective $\mathrm{V}_{2}$ antagonist compound was able to induce a further increase in urine flow rate and a decline in urine osmolality, suggesting that some $\mathrm{V}_{2}$-mediated antidiuretic action is present in the kidney of Brattleboro rats. This antidiuretic influence could be due to the possible secretion of small amounts of vasopressin by peripheral organs such as the adrenals and testes where immunoreactive AVP has been detected (54-56). Alternatively, oxytocin, which is present at enhanced plasmatic concentrations in Brattleboro rats, may be responsible for the residual antidiuretic activity in those animals (57). Oxytocin has indeed been shown to enable Brattleboro rats to raise their urine osmolality, an effect which can be explained by the fact that oxytocin interacts with $V_{2}$ receptors and increases water permeability in the rat collecting duct (58).

In conclusion, the nonpeptide $\mathrm{AVP} \mathrm{V}_{2}$ receptor antagonist, SR 121463A, can be considered as the most potent and selective $\mathrm{V}_{2}$ ligand in both animal and human preparations described so far. SR 121463A is also the most powerful aquaretic agent in rats yet described, with long-lasting oral activity and lack of agonistic properties in vitro and in vivo. Therefore, this molecule is a suitable tool for exploring the pathophysiological role of $V_{2}$ receptors and the therapeutical usefulness of $V_{2}$ blocker aquaretic agents in water-retaining diseases. Thus, these results highlight the promise of obtaining with SR 121463A a full aquaretic drug devoid of agonist effects and suitable for clinical use.

\section{Acknowledgments}

We are grateful to Dr. M. Manning for kindly providing the Linear AVP antagonist (Phaa-D-Tyr(Me)-Phe-Gln-Asn-Arg-Pro-Arg-Tyr$\mathrm{NH}_{2}$ ), and to Dr. L. Kinter for the generous gift of SK\&F 101926. We thank Dr. J. Simiand and her team for the use of the Bio-Image Analyser (BAS 2000, Fuji) and their technical assistance. We also thank A.J. Patacchini for comments on the manuscript and to M. Laborde for her excellent secretarial assistance.

\section{References}

1. Morel, F., M. Imbert-Teboul, and D. Charbardes. 1987. Receptors to vasopressin and other hormones in the mammalian kidney. Kidney Int. 31:512520 .

2. Rouffignac, C. de, B. Corman, and N. Roinel. 1983. Stimulation by antidiuretic hormone of electrolyte tubular reabsorption in rat kidney. Am. J. Physiol. 244(Renal Fluid Electrolyte Physiol. 13):F156-F164.

3. Morel, A., A. O'Carroll, M.J. Brownstein, and S.J. Lolait. 1992. Molecular cloning and expression of a rat V1a arginine vasopressin receptor. Nature (Lond.). 356:523-526.

4. Thibonnier, M., C. Auzan, Z. Madhun, P. Wilkins, L. Berti-Mattera, and E. Clauser. 1994. Molecular cloning, sequencing, and functional expression of a cDNA encoding the human V1a vasopressin receptor. J. Biol. Chem. 269(5): 3304-3310.

5. Sugimoto, T., M. Saito, S. Mochizuki, Y. Watanabe, S. Hashimoto, and H. Kawashima. 1994. Molecular cloning and functional expression of a cDNA encoding the human V1b vasopressin receptor. J. Biol. Chem. 269(53):2708827092.

6. De Keyzer, Y., C. Auzan, F. Lenne, C. Beldjord, M. Thibonnier, X Bertagna, and E. Clauser. 1994. Cloning and characterization of the human V3 pituitary vasopressin receptor. FEBS (Fed. Eur. Biochem. Soc.) Lett. 356:215220

7. Lolait, S.J., A. M. O’Carroll, O.W. McBride, M. Konig, A. Morel, and M.J. Brownstein. 1992. Cloning and characterization of a vasopressin in V2 receptor and possible link to nephrogenic diabetes insipidus. Nature (Lond.). 357: 336-339.

8. Birnbaumer, M., A. Seibold, S. Gilbert, M. Ishido, C. Barberis, A. Antaramian, P. Bradet, and W. Rosenthal. 1992. Molecular cloning of the receptor for human antidiuretic hormone. Nature (Lond.). 357:333-335.

9. Gorbulev, V., H. Büchner, A. Akhundova, and F. Fahrenholz. 1993. Molecular cloning and functional characterization of $\mathrm{V}_{2}$ [8-lysine] vasopressin and oxytocin receptors from a pig kidney cell line. Eur. J. Biochem. 215:1-7.

10. Ufer, E., R. Postina, V. Gorbulev, F. Fahrenholz. 1995. An extracellular residue determines the agonist specificity of V2 vasopressin receptors. FEBS (Fed. Eur. Biochem. Soc.) Lett. 362:19-23.

11. Jard, S., J. Elands, A. Schmidt, and C. Barberis. 1988. Vasopressin and oxytocin receptors: an overview. In Progress in Endocrinology. H. Imura and K. Shizurne, editors. Excerpta Medica, Amsterdam. 1183-1188.

12. Burbach, J.P.H., A.H.A. Roger, S.J. Lolait, F.W. Van Leeuwen, E. Mezey, M. Palkovits, and C. Barberis. 1995. Molecular neurobiology and pharmacology of the vasopressin/oxytocin receptor family. Cell. Mol. Neurobiol. 15(5):573-595.

13. Rosenthal, X., A. Seibold, A. Antaramian, M. Lonergan, M.F. Arthus, G.N. Hendy, M. Birnbaumer, and D.G. Bichet. 1992. Molecular identification of the gene responsible for congenital nephrogenic diabetes insipidus. Nature (Lond.). 359:233-235.

14. Bichet, D.G., M. Lonergan, M.F. Arthus, T.M. Fujiwara, and K. Morgan. 1995. Nephrogenic diabetes insipidus due to mutations in AVPR2 and AQP2. In Neurohypophysis: Recent Progress of Vasopressin and Oxytocin Research. T. Saito, K. Kurokawa, and S. Yoshida, editors. 605-613.

15. Laszlo, F.A., F. Laszlo, and D. De Wied. 1991. Pharmacology and clinical perspectives of vasopressin antagonists. Pharmacol. Rev. 43:73-108.

16. Mah, S.C., and K.G. Hofbauer. 1987. Antagonists of arginine-vasopressin: experimental and clinical applications. Drugs Future. 12:1055-1070.

17. Manning, M., and W.H. Sawyer. 1989. Discovery, development, and some uses of vasopressin and oxytocin antagonists. J. Lab. Clin. Med. 114:617632 .

18. Sorensen, J.B., M.K. Andersen, and H.H. Hansen. 1995. Syndrome of inappropriate secretion of antidiuretic hormone (SIADH) in malignant disease. J. Int. Med. 238:97-110.

19. Goldsmith, S.R., D.L. Dodge-Brown, and A. Katz. 1989. $\alpha 2$-adrenergic stimulation and vasopressin in congestive heart failure. J. Cardiovasc. Pharmacol. $14: 425-429$.

20. Gavras, H. 1991. Role of vasopressin in clinical hypertension and congestive cardiac failure: interaction with the sympathetic nervous system. Clin. Chem. 37/10(B):1828-1830.

21. Allison, N.L., C.R. Albrightson-Winslow, D.P. Brooks, F.L. Stassen, W.F. Huffman, R.M. Stote, and L.B. Kinter. 1988. Species heterogeneity and antidiuretic hormone antagonists: what are the predictors? In Vasopressin: Cellular and Integrative Functions, Allen W. Cowley, Jr., Jean-François Liard, and Dennis A. Ausiello, editors. Raven Press. Ltd., New York. 207-214.

22. Yamamura, Y., H. Ogawa, T. Chihara, K. Kondo, T. Onogawa, S. Nakamura, T. Mori, M. Tominaga, and Y. Yabuuchi. 1991. OPC-21268, an orally effective, nonpeptide vasopressin V1 receptor antagonist. Science (Wash. DC). 252:572-574.

23. Serradeil-Le Gal, C., J. Wagnon, C. Garcia, C. Lacour, P. Guiraudou, B. Christophe, G. Villanova, D. Nisato, J.P. Maffrand, G. Le Fur et al. 1993. Biochemical and pharmacological properties of SR 49059, a new, potent, nonpeptide antagonist of rat and human vasopressin V1a receptors. J. Clin. Invest. 92: 224-231.

24. Yamamura, Y., H. Ogawa, H. Yamashita, T. Chihara, H. Miyamoto, S. 
Nakamura, T. Onogawa, T. Yamashita, T. Hosokawa, T. Mori, M. Tominaga, and Y. Yabuuchi. 1992. Characterization of a novel aquaretic agent, OPC31260 , as an orally effective, nonpeptide vasopressin V2 receptor antagonist. Br. J. Pharmacol. 105:787-791.

25. Ohnishi, A., Y. Orita, R. Okahara, H. Fujihara, T. Inoue, Y. Yamamura, Y. Yabuuchi, and T. Tanaka. 1993. Potent aquaretic agent. A novel nonpeptide selective vasopressin 2 antagonist (OPC-31260) in men. J. Clin. Invest. 92:26532659.

26. Ohnishi, A., Y. Orita, N. Takagi, T. Fujita, T. Toyoki, Y. Ihara, Y. Yamamura, T. Inoue, and T. Tanaka. 1995. Aquaretic effect of a potent, orally active, nonpeptide V2 antagonist in men. J. Pharmacol. Exp. Ther. 272:546-551.

27. Prous, J., N. Mealy, and J. Castañer. 1993. OPC-31260. Drugs Future. 18: 802-804

28. Schmidt, A., S. Audigier, C. Barberis, S. Jard, M. Manning, A.S. Kolodziejezyk, and W.H. Sawyer. 1991. A radioiodinated linear vasopressin antagonist: a ligand with high affinity and specificity for V1A receptors. FEBS (Fed. Eur. Biochem. Soc.) Lett. 282:77-81.

29. Guillon, G., D. Butlen, B. Cantau, T. Barth, and S. Jard. 1982. Kinetic and pharmacological characterization of vasopressin membrane receptors from human kidney medulla: relation of adenylate cyclase activation. Eur. J. Pharmacol. 85:291-304.

30. Guillon, G., M. Trueba, D. Joubert, E. Grazzini, L. Chouinard, M. Coté, M. D. Payet, O. Manzoni, C. Barberis, M. Robert, and N. Gallo-Payet. 1995. Vasopressin stimulates steroid secretion in human adrenal glands:comparison with angiotensin-II effect. Endocrinology. 136:1285-1293.

31. Mouillac, B., B. Chini, M.N Balestre, J. Elands S. Trummp-Kallmeyer, J. Hoflack, M. Hibert, S. Jard, and C. Barberis. 1995. The binding site of neuropeptide vasopressin V1a receptor. Evidence for a major localization within transmembrane regions. J. Biol. Chem. 270(43):25771-25777.

32. Stassen, F.L., R.W. Erickson, W.F. Huffman, J. Stefankiewicz, L. Sulat, and V.D. Wiebelhaus. 1982. Molecular mechanisms of novel antidiuretic antagonist: analysis of the effects on vasopressin binding and adenylate cyclase activation in animal and human kidney. J. Pharmacol. Exp. Ther. 223:50-54.

33. Prpic, V., K.C. Green, P.F. Blackmore, and J.H. Exton, 1983. Vasopressin, angiotensin II-, and $\alpha 1$-adrenergic-induced inhibition of $\mathrm{Ca}^{2+}$ transport by rat liver plasma membranes vesicles. J. Biol. Chem. 259:1382-1385.

34. Bradford, M.M. 1976. A rapid and sensitive method for the quantitation of microgram quantities of protein utilizing the principle of protein-dye binding. Anal. Biochem. 72:248-254.

35. Cheng, Y., and W. Prusoff. 1973. Relationship between the inhibition constant $\left(K_{\mathrm{i}}\right)$ and the concentration of inhibition which cause 50 per cent inhibition (IC50) of an enzymatic reaction. Biochem. Pharmacol. 22:3099-3108.

36. Munson, P.V. and D. Rodbard. 1980. Ligand: a versatile computerized approach for characterization of ligand-binding systems. Anal. Biochem. 107: 220-239.

37. Serradeil-Le Gal, C., D. Raufaste, E. Marty, C. Garcia, J.P. Maffrand, and G. Le Fur. 1996. Autoradiographic localization of vasopressin V1a receptors in the rat kidney using [ $\left.{ }^{3} \mathrm{H}\right]-\mathrm{SR} 49059$. Kidney Int. 50:499-505.

38. Valtin, H. 1992. Genetic models of diabetes insipidus. In Handbook of Physiology, section 8: Renal Physiology. E.E. Windhager, editor. Oxford University Press, New York. 1281-1315.

39. Tribollet, E., C. Barberis, J.J. Dreifuss, and S. Jard. 1988. Autoradiographic localization of vasopressin and oxytocin binding sites in rat kidney. Kidney Int. 33:959-965.

40. Ostrowski, N., S. III Young, M. Knepper, and S. Lolait. 1993. Expression of vasopressin $\mathrm{V}_{1 \mathrm{a}}$ and $\mathrm{V}_{2}$ receptor messenger ribonucleic acid in the liver and kidney of embryonic, developing and adult rats. Endocrinology. 133(3): 1849-1859.

41. Kinter, L.B., W.F. Huffman, and F.L. Stassen. 1988. Antagonists of the antidiuretic activity of vasopressin. Am. J. Physiol. 254(Renal Fluid Electrolyte Physiol. 23):F165-F177.

42. Kinter, L.B., B.E. Ilson, S. Caltabianol, D.K. Jorkasky, D.J. Murphy, H.A. Solleveld, G.R. Rhodes, D.P. Brooks, C.R. Algrightson-Winslow, R.M. Stote, and W.F. Huffman. 1991. Antidiuretic hormone antagonism in humans: are there predictors? In Vasopressin. S. Jard and R. Jamison, editors. Colloque INSERM/John Libbey Eurotext Ltd. 208:321-329.

43. Manning, M., W.H. Sawyer, and H. Design. 1993. Synthesis and some uses of receptor-specific agonists and antagonists of vasopressin and oxytocin. J. Recept. Res. 13:195-214.

44. Serradeil-Le Gal, C., D. Raufaste, E. Marty, C. Garcia, J.P. Maffrand, and G. Le Fur. 1994. Binding of $\left[{ }^{3} \mathrm{H}\right]-\mathrm{SR} 49059$, a potent nonpeptide vasopressin V1a antagonist, to rat and human liver membranes. Biochem. Biophys. Res. Commun. 199:353-360.

45. Pettibone, D.J., T.M. Kishel, C.J. Woyden, B.V. Clineschmidt, M.G. Bock, R.M. Freidenger, D.F. Veber, and P.D. Williams. 1992. Radioligand binding studies reveal marked species differences in the vasopressin V1 receptor of rat, rhesus and human tissues. Life Sci. 50:1953-1958.

46. Williams, P.D., B.V. Clineschmidt, J.M. Erb, R.M. Freidinger, M.T. Guidotti, E.V. Lis, J.M. Pawluczyk, D.J. Pettibone, D.R. Reiss, D.F. Veber, and C.J. Woyden. 1995. 1-\{1-[4-[(N-Acetyl-4-piperidinyl)oxy]-2-methoxybenzoyl]piperidin-4-yl\}-4H-3,1-benzoxazin-2(1H)-one (L-371,257): anew, orally bioavailable, nonpeptide oxytocin antagonist. J. Med. Chem. 38:4634-4636.

47. Liu, J.J., J.R. Chen, B.B. Buxton, C.I. Johnston, and L.M. Burrell. 1995. Potent inhibitory effect of SR 49059, an orally active nonpeptide vasopressin V1a receptor antagonist, on human arterial coronary bypass graft. Clin. Sci. 89: 481-485.

48. Bax, W.A., D. Nisato, E. Bos, and P.R. Saxena. 1994. The effect of novel nonpeptide receptor antagonists on arginine vasopressin-induced contractions of the human isolated coronary artery. Br. J. Pharmacol. 114(Prod. Suppl.):164.

49. Liard, J.F. 1992. cAMP and extrarenal vasopressin V2 receptors in dogs. Am. J. Physiol. 263 (Heart Circ. Physiol. 32):H1888-H1891.

50. Brinton, R.D., and E.A. Brownson. 1993. Vasopressin-induction of cyclic AMP in cultured hippocampal neurons. Dev. Brain Res. 71:101-105.

51. Hirasawa, A., Y. Nakayama, N. Ishiharada, K Honda, R. Saito, G. Tsujimoto, Y. Takamo, and H. Kamiya. 1994. Evidence for the existence of vasopressin $\mathrm{V}_{2}$ receptor mRNA in rat hippocampus. Biochem. Biophys. Res. Commun. 205:1702-1706.

52. Fushimi, K., S. Uchida, Y. Hara, Y. Hirata, F. Marumo, and S. Sasaki. 1993. Cloning and expression of apical membrane water channel of rat kidney collecting tubule. Nature (Lond.). 361:549-552.

53. Nielsen, S., and M. Knepper. 1995. Vasopressin regulation of aquaporin 2 water channels in kidney collecting duct. In Neurohypophysis: Recent Progress in Vasopressin and Oxytocin Research. T. Saito, K. Urokawa, and S. Yoshida, editors. Elsevier Science B.V., Amsterdam, The Netherlands. 473-483.

54. Wathes, D.C., R.W. Swann, S.D. Birkett, D.G. Porter, and B.T. Pickering. 1983. Characterization of oxytocin, vasopressin, and neurophysin from the bovine corpus luteum. Endocrinology. 113:693-698.

55. Nicholson, H.D., 1983. More steroidogenic tissues containing oxytocin and vasopressin : human testis and fetal adrenal. Acta endocr. 103(suppl. 256): 243

56. Ang, V.T., and J.S. Jenkins. 1984. Neurohypophysial hormones in the adrenal medulla. J. Clin. Endocrinol. Metab. 58:688-691.

57. Balment, R.J., M.J. Brimble, and M.L. Forsling. 1982. Oxytocin release and renal actions in normal and Brattleboro rats. Ann. NY Acad. Sci. USA. 394 241-253.

58. Chou, C.L., S.R. DiGiovanni, A. Luther, S.J. Lolait, and M.A. Knepper. 1995. Oxytocin as an antidiuretic hormone II. Role of V2 vasopressin receptor. Am. J. Physiol. 269 (Renal Fluid Electrolyte Physiol. 38):F78-F85. 